\title{
Morphological, cultural and pathogenic variability in Alternaria brassicae, the causing agent of black spot of rapeseed and mustard
}

\author{
B. S. Bhatiya*, K. S. Bisht, Pankaj Rautela and R. P. Awasthi \\ Nagar- 263145 (Uttarakhand), INDIA \\ *Corresponding author. E-mail: Bhupendra_Patho@rediffmail.com \\ Received: August 31, 2015; Revised received: February 23, 2016; Accepted: May 23, 2016
}

Center of Advance Studies, Department of Plant Pathology, College of Agriculture, G.B.P.U.A.T., Pantnagar, U. S.

\begin{abstract}
The study on pathogenic diversity of twenty isolates of Alternaria brassicae collected from different locations of Uttarakhand and Central Uttar Pradesh infecting Brassica species (Brassica rapa, Brassica juncea and Eruca sativa) revealed that there was a distinct difference among isolates in terms of mycelial growth, spore length, width, spore beak length and width. The average spore length varied from $21.23 \mu \mathrm{m}$ to $38.13 \mu \mathrm{m}$ with minimum of

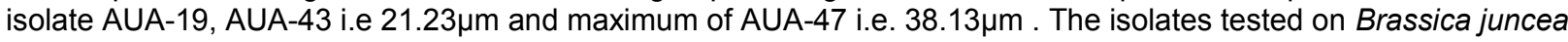
var.Varuna in green house conditions revealed that all the twenty isolates behaved differently. Among all the isolates, Brassica juncea isolates i.e. AUA-25, AUA-39, AUA-41, AUA-47, AUA-19, AUA-24, AUA-22, AUA-21, AUA -31, AUA-43 and AUA-45 from Uttarakhand, and AUP-29 from Central Uttar Pradesh can be grouped into highly pathogenic with range of Alternaria spot size i.e. $5.03-8.30 \mathrm{~mm}$ in diameter, while isolate of Eruca sativa i.e. AUA-38 was found least pathogenic with 1.63mm in dia. and eight isolates AUA-18, AUA-20, AUA-23, AUP-28, AUA-32, AUA-33 and AUA-36 were found moderately pathogenic. This study will be useful in developing integrated management strategies of Alternaria leaf spot and breeding programs of oilseed crops (Brassica sp.).
\end{abstract}

Keywords: Alternaria brassicae, cultural, morphology, pathogenicity, variability

\section{INTRODUCTION}

Rapeseed -mustard is important rabi oilseed crops grown all over India with low average productivity for which diseases are major contributing factors. Among the various diseases occurring on rapeseed-mustard, Alternaria black spot incited by Alternaria brassicae (Berk.) Sacc. is one of the most important and devastating disease. It has been reported to cause variable losses in yield, depending upon disease severity. Yield loss to the extent of 47 per cent has been reported (Chattopadhyay, 2008; Meena et al., 2010). There are a number of reports on the existence of variability on the basis of mycelial growth, morphology and sporulation among different isolates of $A$. brassicae from different geographical regions of India (Ansari et al.,1989; Kaur et al., 2007; Goyal et al.,2011) .Since the crop and disease are of paramount importance, the present investigation focused on evaluation of morphological, cultural and pathogenic variability of twenty isolates of $A$. brassicae of Brassica species from Uttarakhand and Central Uttar Pradesh that is essential to design disease management strategies for different places of India by breeding resistant cultivars. It has also been determined whether morphological variations among $A$. brassicae isolates have any relationship with the pathogenic variability.

\section{MATERIALS AND METHODS}

Collection of $\boldsymbol{A}$. brassicae isolates:Infected leaves exhibiting different types of typical symptoms of Alternaria leaf spot disease, usually with concentric rings were collected separately from different genotypes of Brassica juncea, B. rapa and Eruca sativa from Uttarakhand, Central U.P. and the Crop Research Centre, G.B. Pant University of Agriculture and Technology. The leaf samples were brought to the laboratory for microscopic examination and isolation. (Table 1).

Isolation of the fungus: The infected leaves of the Brassica species were thoroughly washed in tap water and separately cut into small pieces about $0.5 \mathrm{~cm}$ size. These selected infected spots were washed 3 to 4 times in sterilized distilled water and then surface sterilized by dipping in $0.1 \% \mathrm{HgCl}_{2}$ solution for 30 second, followed by washing with sterilized water 3 to 4 times, which were then aseptically transferred between the two fold of sterilized blotting paper to remove excess amount of water to prevent bacterial contamination. After that these pieces were transferred aseptically into Petri dishes containing sterilized potato dextrose agar (PDA) and incubated at $25 \pm 2^{\circ} \mathrm{C}$ for seven days. After seven days growing mycelium was sub-cultured on fresh PDA plates. In this way cultures of different isolates were obtained. 
Identification and purification of the fungus: Temporary slides of the cultures were prepared in lactophenol and examined under compound microscope for the mycelial and spore characteristics. On the basis of their conidiophore and conidial morphology as described by Simmons (2007), the pathogen was identified as A. brassicae (Berk.) Sacc. The pathogen of A. brassicae was purified by single spore technique. Single spore technique was used for maintaining the purity of each isolate (Gattani., 1954). Thus various isolates collected from different locations were designated as Alternaria Uttarakhand Isolate (AUA) and Alternaria central U.P. isolates (AUP).

Evaluation of morphological variability of different isolates of $A$. brassicae: Morphological variability among the 20 isolates of $A$. brassicae was studied using micrometry technique ( Meena et al., 2005). About 20 to 25 spore per slide were examined at $40 \mathrm{X}$ magnification by light microscope. The size and shape of conidia was measured by using ocular and stage micrometer. Numbers of transverse septa were also recorded.

Cultural characteristics of different isolates of A. brassicae: The cultural characteristics of each isolates like colony, color, texture, growth, shape, margin and zonation were recorded by direct observation of 15 day old culture-grown on PDA incubated at $25 \pm 2^{\circ} \mathrm{C}$ temperature.

Pathogenic variability of different isolates of A. brassicae: In order to confirm the identification of the disease and its causal agent, the pathogenicity test was conducted under polyhouse conditions under pot experiments using B. juncea var. Varuna. Seedlings were raised in pots filled with sterilized soil. Pathogenicity test of the fungus was done, on one month old healthy plants of B. juncea var. Varuna grown in pots under glasshouse condition. Fifteen days old cultures of Alternaria brassicae on PDA was taken, blended

Table 1. Isolates of Alternaria brassicae collected from infected leaves of different oilseed Brassica cultivars from Uttarakhand and central Uttar Pradesh.

\begin{tabular}{|c|c|c|c|c|c|c|c|}
\hline S. N. & Code & Oilseed Brassica spp. & Variety & Plant part & Place of collection & \multicolumn{2}{|c|}{ Geographical Data } \\
\hline 1 & AUA-18 & Brassica rapa & $\begin{array}{l}\text { Yellow Sarson } \\
\text { Local }\end{array}$ & Leaf & Pantnagar & $\begin{array}{l}\text { Latitude } \\
\text { Longitude }\end{array}$ & $\begin{array}{l}28^{\circ} 58^{\prime} \mathrm{N} \\
: 79^{\circ} 25^{\prime} \mathrm{E}\end{array}$ \\
\hline 2 & AUA-19 & B. juncea & EC-399301 & Leaf & Pantnagar & $\begin{array}{l}\text { Latitude } \\
\text { Longitude }\end{array}$ & $\begin{array}{l}: 28^{\circ} 58^{\prime} \mathrm{N} \\
: \quad 79^{\circ} 25^{\prime} \mathrm{E}\end{array}$ \\
\hline 3 & AUA-20 & B. juncea & Mustard Local & Leaf & Sitarganj & $\begin{array}{l}\text { Latitude } \\
\text { Longitude }\end{array}$ & $\begin{array}{l}: \quad 28^{\circ} 56^{\prime} \mathrm{N} \\
: \quad 79^{\circ} 42^{\prime} \mathrm{E}\end{array}$ \\
\hline 4 & AUA-21 & B. juncea & EC-414317 & Leaf & Pantnagar & $\begin{array}{l}\text { Latitude } \\
\text { Longitude }\end{array}$ & $\begin{array}{l}: 28^{\circ} 58^{\prime} \mathrm{N} \\
: \quad 79^{\circ} 25^{\prime} \mathrm{E}\end{array}$ \\
\hline 5 & AUA-22 & B. juncea & EC-399296 & Leaf & Pantnagar & $\begin{array}{l}\text { Latitude } \\
\text { Longitude }\end{array}$ & $\begin{array}{l}: 28^{\circ} 58^{\prime} \mathrm{N} \\
: \quad 79^{\circ} 25^{\prime} \mathrm{E}\end{array}$ \\
\hline 6 & AUA-23 & B. juncea & EC-414322 & Leaf & Pantnagar & $\begin{array}{l}\text { Latitude } \\
\text { Longitude }\end{array}$ & $\begin{array}{l}: \quad 28^{\circ} 58^{\prime} \mathrm{N} \\
: \quad 79^{\circ} 25^{\prime} \mathrm{E}\end{array}$ \\
\hline 7 & AUA-24 & B. juncea & PWR-9338 & Leaf & Pantnagar & $\begin{array}{l}\text { Latitude } \\
\text { Longitude }\end{array}$ & $\begin{array}{l}: \quad 28^{\circ} 58^{\prime} \mathrm{N} \\
: \quad 79^{\circ} 25^{\prime} \mathrm{E}\end{array}$ \\
\hline 8 & AUA-25 & B. juncea & Mustard & Leaf & $\begin{array}{l}\text { Halduchaud Hald- } \\
\text { wani }\end{array}$ & $\begin{array}{l}\text { Latitude } \\
\text { Longitude }\end{array}$ & $\begin{array}{l}: \quad 29^{\circ} 13^{\prime} \mathrm{N} \\
: \quad 79^{\circ} 31^{\prime} \mathrm{E}\end{array}$ \\
\hline 9 & AUP-28 & B. rapa & Yellow Sarson & Leaf & Kanpur & $\begin{array}{l}\text { Latitude } \\
\text { Longitude }\end{array}$ & $\begin{array}{l}: \quad 27^{\circ} 25^{\prime} \mathrm{N} \\
: \quad 80^{\circ} 07^{\prime} \mathrm{E}\end{array}$ \\
\hline 10 & AUP-29 & B. juncea & Mustard Local & Leaf & Hardoi & $\begin{array}{l}\text { Latitude } \\
\text { Longitude }\end{array}$ & $\begin{array}{l}: 27^{\circ} 25^{\prime} \mathrm{N} \\
: 80^{\circ} 07^{\prime} \mathrm{E}\end{array}$ \\
\hline 11 & AUA-31 & B. juncea & Mustard Local & Leaf & $\begin{array}{l}\text { Indra Nagar Hald- } \\
\text { wani }\end{array}$ & $\begin{array}{l}\text { Latitude } \\
\text { Longitude }\end{array}$ & $\begin{array}{l}: \quad 29^{\circ} 13 \mathrm{~N} \\
: \quad 79^{\circ} 31^{\prime} \mathrm{E}\end{array}$ \\
\hline 12 & AUA-32 & B. juncea & Mustard Local & Leaf & RishiKesh & $\begin{array}{l}\text { Latitude : } \\
\text { Longitud }\end{array}$ & $\begin{array}{l}30^{\circ} 06^{\prime} 12^{\prime \prime} \mathrm{N} \\
: 78^{\circ} 17^{\prime} 41^{\prime \prime} \mathrm{E}\end{array}$ \\
\hline 13 & AUA-33 & B. juncea & PAB-9511 & Leaf & Pantnagar & $\begin{array}{l}\text { Latitude } \\
\text { Longitude }\end{array}$ & $\begin{array}{l}: 28^{\circ} 58^{\prime} \mathrm{N} \\
: 79^{\circ} 25^{\prime} \mathrm{E}\end{array}$ \\
\hline 14 & AUA-36 & B. juncea & EC-411322 & Leaf & Pantnagar & $\begin{array}{l}\text { Latitude } \\
\text { Longitude }\end{array}$ & $\begin{array}{l}: 28^{\circ} 58^{\prime} \mathrm{N} \\
: 79^{\circ} 25^{\prime} \mathrm{E}\end{array}$ \\
\hline 15 & AUA-38 & $\begin{array}{l}\text { Eureca. } \\
\text { sativa }\end{array}$ & E. sativa & Leaf & Pantnagar & $\begin{array}{l}\text { Latitude } \\
\text { Longitude }\end{array}$ & $\begin{array}{l}: 28^{\circ} 58^{\prime} \mathrm{N} \\
: 79^{\circ} 25^{\prime} \mathrm{E}\end{array}$ \\
\hline 16 & AUA-39 & B. juncea & Mustard & Leaf & Kathangri Sitarganj & $\begin{array}{l}\text { Latitude } \\
\text { Longitude }\end{array}$ & $\begin{array}{l}: 28^{\circ} 56^{\prime} \mathrm{N} \\
: 79^{\circ} 42^{\prime} \mathrm{E}\end{array}$ \\
\hline 17 & AUA-41 & B. juncea & Mustard & Leaf & $\begin{array}{l}\text { Danibangar Hald- } \\
\text { wani }\end{array}$ & $\begin{array}{l}\text { Latitude } \\
\text { Longitude }\end{array}$ & $\begin{array}{l}: 29^{\circ} 13^{\prime} \mathrm{N} \\
: 79^{\circ} 31^{\prime} \mathrm{E}\end{array}$ \\
\hline 18 & AUA-43 & B. juncea & Mustard & Leaf & Maghera Haldwani & $\begin{array}{l}\text { Latitude : } 2 \\
\text { Longitude }\end{array}$ & $\begin{array}{l}9^{\circ} 13^{\prime} \mathrm{N} \\
: 79^{\circ} 31^{\prime} \mathrm{E}\end{array}$ \\
\hline 19 & AUA-45 & B. juncea & Mustard & Leaf & Pantnagar & $\begin{array}{l}\text { Latitude } \\
\text { Longitude }\end{array}$ & $\begin{array}{l}: 28^{\circ} 58^{\prime} \mathrm{N} \\
: 79^{\circ} 25^{\prime} \mathrm{E}\end{array}$ \\
\hline 20 & AUA-47 & B. juncea & PAB-2002 & Leaf & Pantnagar & $\begin{array}{l}\text { Latitude } \\
\text { Longitude }\end{array}$ & $\begin{array}{l}: 28^{\circ} 58^{\prime} \mathrm{N} \\
: 79^{\circ} 25^{\prime} \mathrm{E} \\
\end{array}$ \\
\hline
\end{tabular}


B. S. Bhatiya et al. / J. Appl. \& Nat. Sci. 8 (2): 840 - 845 (2016)

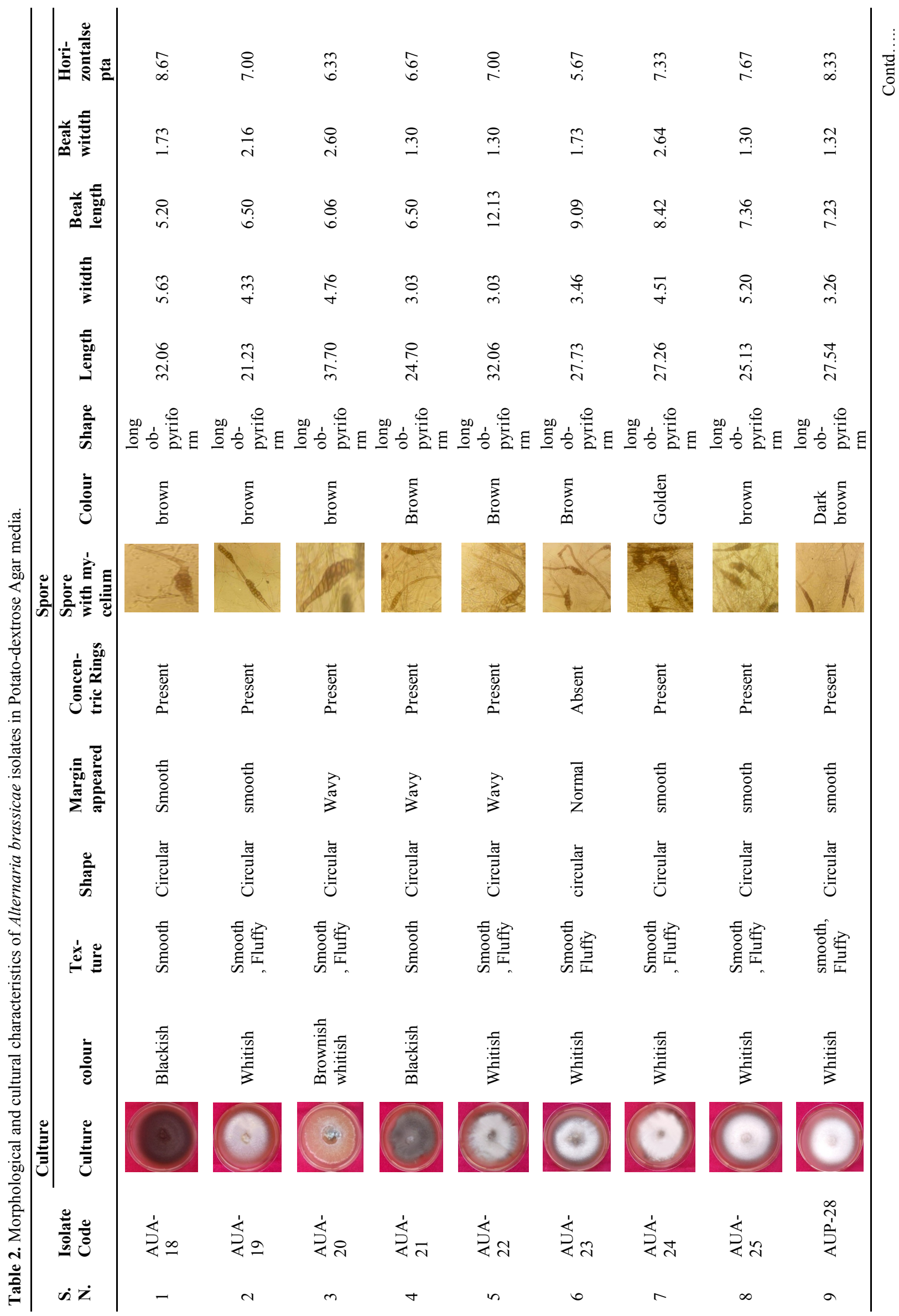




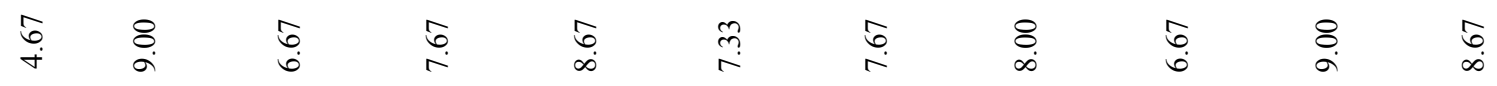

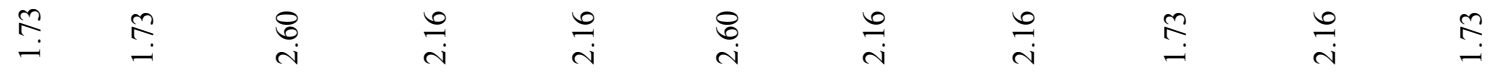

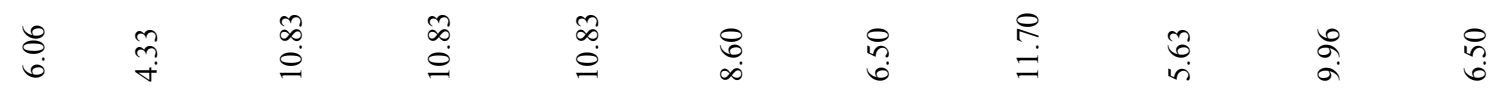

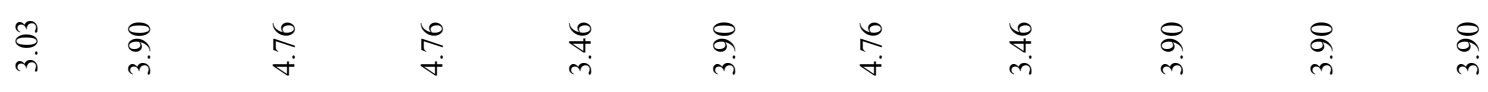

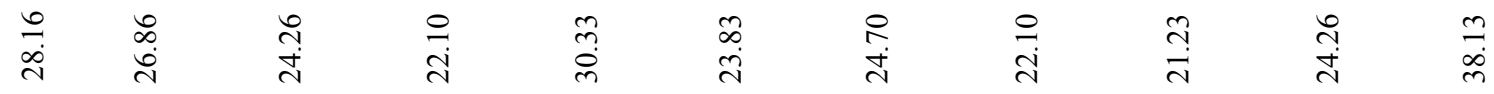

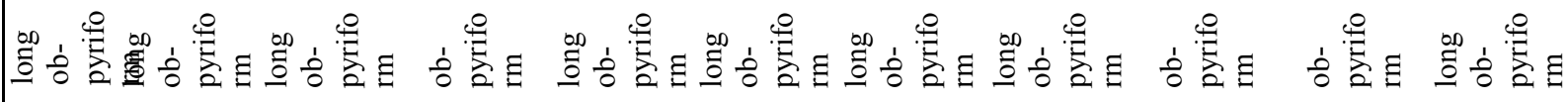

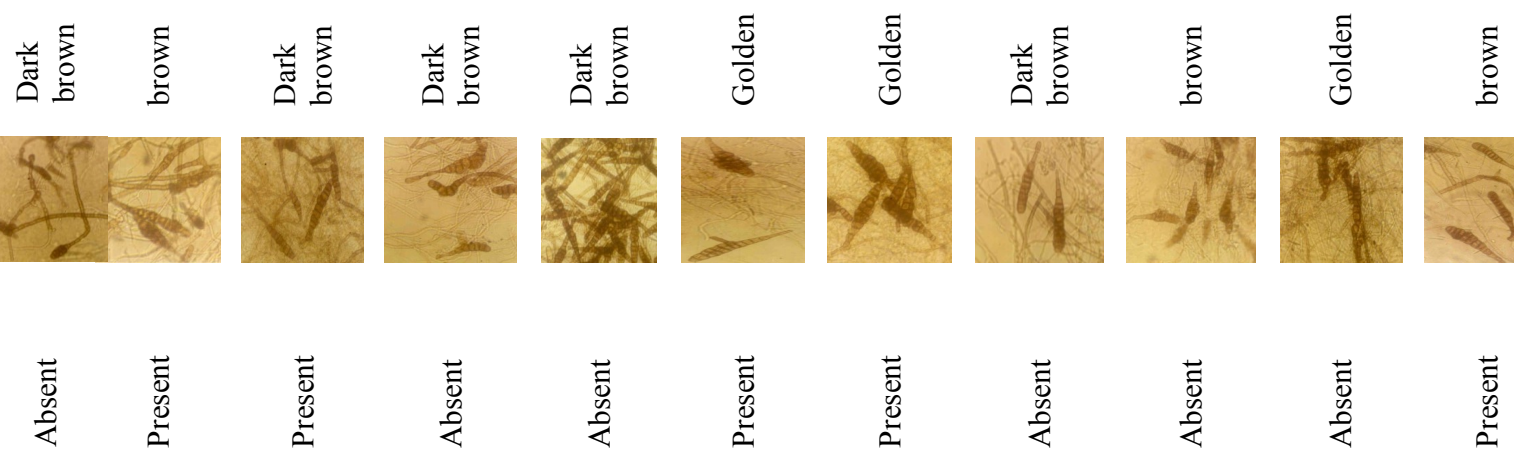

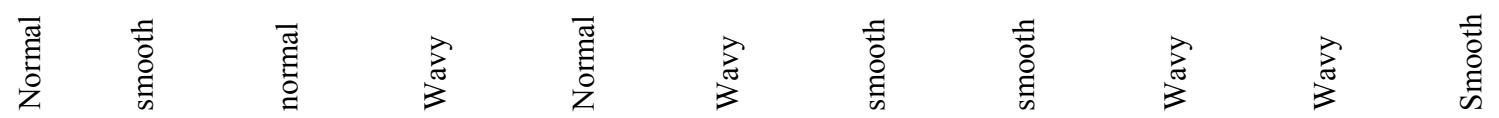

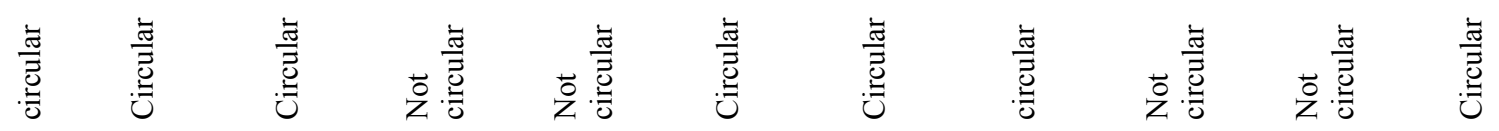

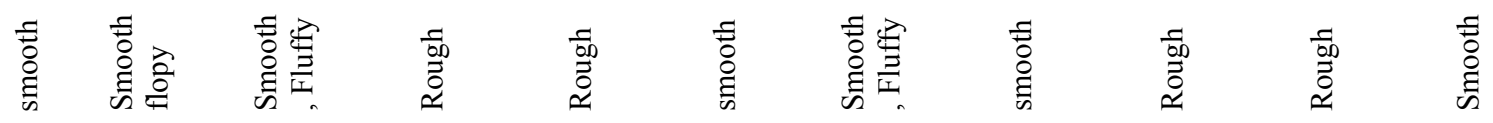

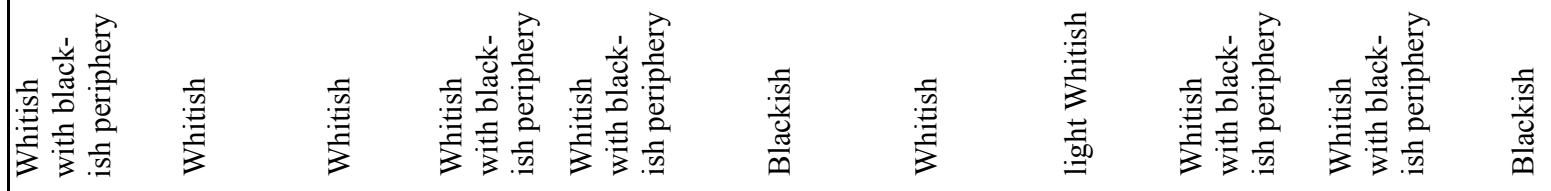
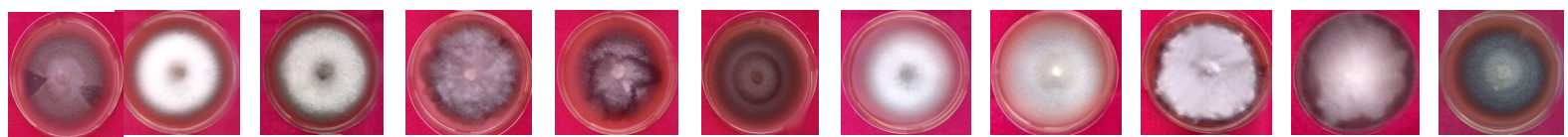

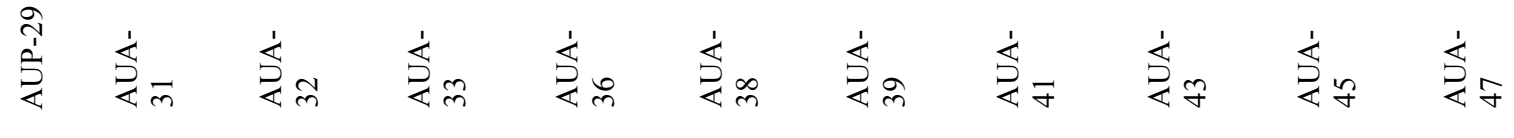

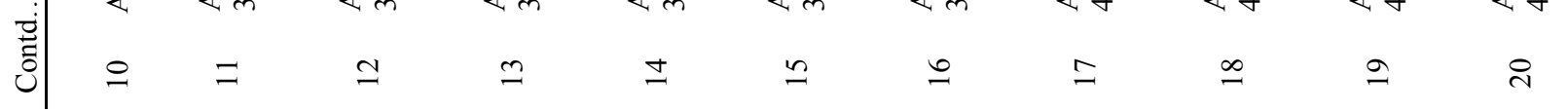


Table 3. Pathogenicity test of A. brassicae isolates on Brassica juncea var. Varuna.

\begin{tabular}{llll}
\hline S.N. & Different isolates & Average size of Alternaria spots (in mm) & Pathogenicity \\
\hline 1 & AUA-18 & 2.80 & ++ \\
2 & AUA-19 & 6.17 & +++ \\
3 & AUA-20 & 4.77 & ++ \\
4 & AUA-21 & 5.03 & +++ \\
5 & AUA-22 & 5.17 & +++ \\
6 & AUA-23 & 4.23 & ++ \\
7 & AUA-24 & 6.20 & +++ \\
8 & AUA-25 & 8.30 & +++ \\
9 & AUP-28 & 2.13 & ++ \\
10 & AUP-29 & 5.60 & +++ \\
11 & AUA-31 & 5.67 & +++ \\
12 & AUA-32 & 3.63 & ++ \\
13 & AUA-33 & 2.67 & ++ \\
14 & AUA-36 & 3.47 & ++ \\
15 & AUA-38 & 1.63 & + \\
16 & AUA-39 & 6.47 & +++ \\
17 & AUA-41 & 7.10 & +++ \\
18 & AUA-43 & 5.87 & +++ \\
19 & AUA-45 & 6.70 & +++ \\
20 & AUA-47 & 6.29 & +++ \\
\hline
\end{tabular}

Symptoms observed were ranked as $(+)$ for spots with diameter $<2 \mathrm{~mm},(++)$ for spots with diameter $2-5 \mathrm{~mm}$, and (+++) for spots with diameter above $5 \mathrm{~mm}$

with sterilized distilled water, and filtered through cheesecloth. The spore suspensions (15.00 to 20.00 spores/ $\mathrm{ml}$.) were taken in a $100 \mathrm{ml}$ atomizer separately for each isolate. All the leaves of the Brassica species were inoculated in triplicate for each isolate of $A$. brassicae and one set was kept as check in which only sterilized water was sprayed. The inoculated plants were separately kept in moist chambers isolate-wise. Symptoms observed were ranked as (-) for no symptom, $(+)$ for spots with diameter $<2 \mathrm{~mm},(++)$ for spots with diameter $2-5 \mathrm{~mm}$ and $(+++)$ for spots with diameter above $5 \mathrm{~mm}$. Experiments were conducted in completely randomized design (CRD).

\section{RESULTS AND DISCUSSION}

Morphological variability among isolates: Significant $(\mathrm{P}<0.05)$ morphological variability was observed among all 20 isolates of $A$. brassicae of Brassica species i.e. AUA-18, AUP-28 from rapeseed crop (Brassica rapa), AUA-19, AUA-20, AUA-21, AUA22, AUA-23, AUA-24, AUA-25, AUP-29, AUA-31, AUA-32, AUA-33, AUA-36, AUA-39, AUA-41, AUA -43, AUA-45, AUA-47 from mustard (Brassica juncea) AUA-38 from taramira (Eruca sativa). (Fig. 1) in respect of spore length, spore width, spore beak length, spore beak width and number of horizontal septa of $A$. brassicae. Maximum spore length of $A$. brassicae was recorded for AUA-47 $(38.13 \mu \mathrm{m})$ and it was significantly different to AUA-19 $(21.23 \mu \mathrm{m})$, AUA-21 $(24.70 \mu \mathrm{m})$, AUA-25 $(25.13 \mu \mathrm{m})$, AUA-32 $(24.26 \mu \mathrm{m})$, AUA-33 $(22.10 \mu \mathrm{m})$, AUA-38 $(23.83 \mu \mathrm{m})$,

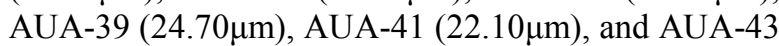
$(21.23 \mu \mathrm{m})$ and minimum spore length was recorded for the isolate AUA-19 and AUA-43 $(21.23 \mu \mathrm{m})$, followed by AUA-33 and AUA-41(22.10 $\mu \mathrm{m})$. Maximum spore width was recorded for AUA-18 $(5.63 \mu \mathrm{m})$ and it was significantly higher than AUA-21, AUA-22 and AUP29 for which minimum spore width (3.03 um) was recorded (Table 2). Minimum spore beak length was recorded for AUA-31 $(4.33 \mu \mathrm{m})$ and it was at par with all isolates except AUA-22 $(12.13 \mu \mathrm{m})$, which recorded maximum length. Maximum spore beak width was recorded for AUA-24 $(2.64 \mu \mathrm{m})$ and minimum spore beak width was recorded for the isolate, AUA-21, AUA-22 and AUA-25 $(1.30 \mu \mathrm{m})$ followed by AUA-18, AUA-23, AUP-29, AUA-31, AUA-43, and AUA-47 $(1.73 \mu \mathrm{m})$ and these were at par with all other isolates. Highest number of horizontal septa was shown by AUA-31 and AUA-45 (9.0) followed by AUA-18, AUA-36 and AUA-47, whereas AUA-20 (6.33) showed minimum number of horizontal septa (Table 2). These results are in accordance with earlier workers (Awasthi and Kolte, 1989;; Meena et al., 2005; Sharma et al., 2013; Pramila et al., 2015, who observed morphological variability in Alternaria brassicae isolates of difference places of India. Goyal et al. (2011) reported variation in conidial morphology, mycelial growth, sporulation of thirteen isolates of $A$. brassicae collected from seven states of India. Similarly, Meena et al., 2005; Sharma et al., 2013; Pramila et al., 2015 reported variability in the morphological characteristics in A. brassicae isolates of different places of India.

Cultural characteristic of $A$. brassicae isolates: Variations in linear growth and color of the colony were observed among all 20 isolates of A. brassicae. The color of the colonies and the spore grown on PDA showed little variation. The color of the A. brassicae isolates varied from white, brownish white to black, texture of the colony from cottony to fluffy, colony margin from wavy, smooth to rough. Mycelial color varied from brown to golden and spores were golden 
and brown in color and were generally long obpyriform in shape with long beak (Table 2). The results are in accordance with Ansari et al., 1989; Patni et al., 2005; Kaur et al., 2007; Sharma et al., 2013 who observed cultural variability in Alternaria species in respect of mycelial growth and sporulation.

Pathogenic variability among $\boldsymbol{A}$. brassicae isolates: Different isolates of $A$. brassicae of Brassica species (Brassica rapa, Brassica juncea and Eruca sativa) showed pathogenic variability on host $B$. juncea cultivar Varuna. All the $A$. brassicae isolates from rapeseed (Brassica rapa) mustard (Brassica juncea) and Rocked salad (Eruca sativa) were found to be pathogenic in nature (Table 3). Among them, isolates of Brassica juncea i.e. AUA-19, AUA-21, AUA-22, AUA-24, AUA-25, AUA-31, AUA-39, AUA-41, AUA-43, AUA-45, AUA47 and AUP-29 were found to be highly pathogenic as the spots size produced by them were $>5 \mathrm{~mm}$ in diameter. Isolates AUA-20, AUA-23, AUA-32, AUA-33, \& AUA-36 from Brassica juncea and AUA-18 \& AUP-28 from Brassica rapa were moderately pathogenic as spots size produced by them were $2-5 \mathrm{~mm}$ in diameter, while isolate of E. sativa i.e. AUA-38 was least pathogenic as spots size produced $<2 \mathrm{~mm}$ in diameter. Similar results were obtained by Michereff, et al., 2003 who studied 38 Alternaria brassicicola isolates of cabbage and cauliflower (Brassica oleracea) and estimated pathogenic variability based on disease development. Pramila et al. (2013) who reported pathogenic variability based on size of spots among 10 isolates of Alternaria brassicae of Indian mustard.

\section{Conclusion}

The findings of present investigations clearly demonstrated that overall morphological, cultural and pathogenic variability did exist in $A$. brassicae and showed high leval of derangement with no clear grouping of $A$. brassicae and no corelation in studies among the morphological, cultural and pathogenic variability of $A$. brassicae isolates. But in this study 4 isolates of A. brassicae from Pantnagar i.e AUA-33, AUA-36, AUA-23 (B. juncea), AUA-18 (B.rapa), AUA-20 (B. Juncea) from Sitargang, AUP-28 (B. rapa) from Kanpur and AUA-32 (B. juncea) from Rishikesh were found moderately pathogenic with $2.13-4.77 \mathrm{~mm}$ dia. spot size, whereas isolate AUA-38 (Eruca sativa) from Pantnagar was found least pathogenic with $1.63 \mathrm{~mm}$ dia. size of Alternaria leaf spot. The determination of pathogenic variability among $A$. brassicae isolates is fundamental to guide the development of appropriate strategies for disease management according to different climatic zones. This result of pathogenic variability will be useful in developing integrated management strategies of Alternaria leaf spot and breeding programs for the crops of Brassica sp.

\section{REFERENCES}

Ansari, N.A., Khan, M.W. and Muheet, A. (1989). Effect of some factors on growth and sporulation of Alternaria brassicae causing Alternaria blight of rapeseed and mustard. Acta Bot. Ind. 17: 49-53.

Awasthi, R.P. and Kolte, S.J. (1989). Variability in Alternaria brassicae affecting rapeseed and mustard. Indian Phytopath. 42: 275

Chattopadhyay, C., Agrawal, R., Kumar, A., Bhar, L.M., Meena, P.D., Meena, R.L., Khan, S.A., Chattopadhyay, A.K., Awasthi, R.P., Singh, S.N., Chakravarthy, N.V.K., Kumar, A., Singh, R.B. and Bhunia, C.K. (2008). Epidemiology and forecasting of Alternaria blight of oilseed Brassica in India - a case study. $J$. Plant Dis. Protect. 112:351-365.

Gattani, M.L. (1954). Agar plate spore germination method for testing fungicides. Phytopathology, 44: 113-115

Goyal, P., Chahar, M., Mathur, A.P., Kumar, A. and Chattopadhyay, C. (2011). Morphological and cultural variation in different oilseed Brassica isolates of Alternaria brassicae from different geographical regions of India. Indian J. Agric. Sci. 81 (11): 1052-1058.

Kaur, S., Singh, G. and Banga S.S. (2007). Documenting variation in Alternaria brassicae isolates based on conidial morphology, fungicidal sensitivity and molecular profile. In: Proceeding of the 12th International Rapeseed Congress, 26-30 Mar 2007, GCIRC, Wuhan, China. 4:87-89.

Meena, P.D., Gupta, R., Rani, A., Sharma, P., Rai, P.K. and Chowdappa, P. (2010). Morphological and cultural variability among Alternaria brassicae isolates from India. National Symposium on "Molecular Approaches for Management of Fungal Diseases of Crop Plants." Bangalore. pp. 184-185.

Meena, P.D., Chattopadhyay, C., Kumar, V.R., Meena, R.L. and Rana, U.S. (2005). Spore behaviour in atmosphere and trends in variability of Alternaria brassicae population in India. J. Mycol. Plant Pathol. 35:511.

Michereff, S.J., Marissônia, A.N., Otacílio, M.R., Jearbes, A.S. and Eduardo, S.G.M. (2003). Variabilidade de Isolados de Alternaria brassicicola no Estado de Pernambuco, 1Área de Fitossanidade, Departamento de Agronomia, Universidade Federal Rural de Pernambuco, CEP 52171-900, Recife, PE.

Patni, C.S., Kolte, S.J. and Awasthi, R.P. (2005). Cultural variability of Alternaria brassicae, causing Alternaria blight of mustard. Annals of Plant Physiology. 19(2): 231-242.

Pramila, Giri, P., Tasleem, M., Taj, G., Mal, R. and Kumar, A. (2014). Morphological, cultural, pathogenic and molecular variability amongst India isolates of Alternaria brassicae in Uttarakhand. African Journal of Biotechnology, 13(3): 441-448

Sharma, M., Deep, S., Bhati, D.S., Chowdappa, P., Selvamani, R. and Sharma, P. (2013). Morphological, cultural, pathogenic and molecular studies of Alternaria brassicae infecting cauliflower and mustard in India. African Journal of Microbiology Research, 7(26): 3351-3363.

Simmons, E.G. (2007). Alternaria:an identification manual. CBS, Utrecht publisher, Netherland. 